\title{
当院における脛骨プラトー骨折の治療成績
}

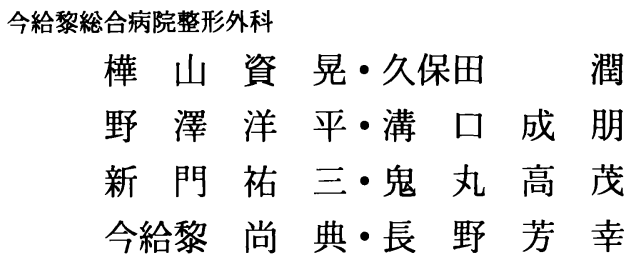

\section{Treatment of the Tibial Plateau Fracture}

by

Sukeaki Kabayama, Jun Kubota, Youhei Nozawa, Narutomo Mizoguchi, Hiromi Shinkado, Takashige Onimaru,

Takanori Imakiire, Yoshiyuki Nagano

Department of Orthopaedic Surgery, Imakiire General Hospital

We evaluated the results of tibial Plateau fractures.

Subjects consisted of 22 patients ( 22 knees) between the age of 16 and 75 years (average : 54 years).

Twenty fractures were treated by surgery and two treated by cast.

The fractures were classified according to Hohl's classification.

The clinical results were evaluated according to Hohl and Luck's criteria.

In terms of anatomical criteria, $77.3 \%$ of the cases were good or excellent, $86.3 \%$ were good or excellent in functional creteria.

In some cases, the depressed parts were noted to sink suring the treatment.

Most of the fractures were in the middle or posterior aspect of the joints.

3 dimensional CT was useful to obtain a more accurate evaluation of the depressed area.

Key words : Tibia (脛骨), tibial plateau (脛骨プラトー), fracture (骨折)

はじめに

脛骨プラトー骨折は, 荷重関節の関節内骨折であり, 軟部組織の合併損傷も多く, 観血的治療を要すること が多い，今回我々は，その治療成績について検討した。

\section{対象亡方法}

対象は男性 10 例女性 12 例, 計 22 例で，年令は 16 才〜 75 才, 平均 54 才で, 経過観察期間は 3 か月〜 5 年 11 か月, 平均 2 年 8 か月であった。骨折型は Hohl の分類 ${ }^{1)}$, 術後評価は Hohl \& Luck の判定基準 ${ }^{2)}$
用いて行われた。 治療法は保存的治療 2 例, 観血的治 療 20 例で, 観血的治療は症例に応じ tibia bolt, buttress plate 等を用い内固定を行ない, 20 例中 8 例に 腸骨からの骨移植が行われた。

\section{結果}

骨折型は, I 型 3 例 (13.6\%), III型 8 例 (36.4\%), IV型 1 例 (4.5\%), VI型 10 例（45.4\%）であった。軟 部組織損傷は MCL 損傷が 5 例 (22.7\%) と最多で, ACL 損傷 2 例 ( $9 \%), \mathrm{MCL} \cdot \mathrm{ACL}$ 合併損傷が 1 例 (4.5\%) であった. 術後 ROM 訓練は可能な限り早期 
にCPM を用いて行われ, 多発外傷例を除いて, 術後 3 日目から 2 週間目までに開始された。 又, 術後免荷 期間は $8 \sim 12$ 週間であった。術後成績を Hohl \& Luck の判定基準 ${ }^{2)}$ に従って評価すると, Good 以上 のものが, 解剖学的成績で $77.3 \%$, 機能的成績で 86.3 \%であり,ほぼ満足のいく結果であった（図一 1 ).

又, 骨移植の有無による成績の比較を行うと, 骨移植 症例では Good 以上のものが, 解剖学的及び機能的成 績共に $87.5 \%$ であるのに対し, 非移植症例では, 解剖 学的成績が $75 \%$, 機能的成績が $66.7 \%$ と劣っていた。

\section{症例}

症例 1, 67 才女性. Hohl の分類の I 型で保存的治 療例である．受傷時外側プラト一前方を中心に約 3 $\mathrm{mm}$ の陥凹を認めたが，保存的治療とした．4 週目 から PTB にて歩行を開始したが，陥凹が進行したた め, 受傷後 2 か月目から再び PTB を用いて歩行再開 した。陷凹は $7 \mathrm{~mm}$ となった。解剖学的成績は Good, 機能的成績は Excellent であったが，手術的に陥凹を 予防すべきであったと思われる（図ー2）。

症例 2, 69 才男性. Hohl の分類正型で, 軟部組織 損傷はなく，外側プラトー部に約 $5 \mathrm{~mm}$ の陥凹が認 められた，術前 3 次元 CT にてむ，プラト一前方から 荷重部にかけての陥凹が認められた。腸骨からの全層

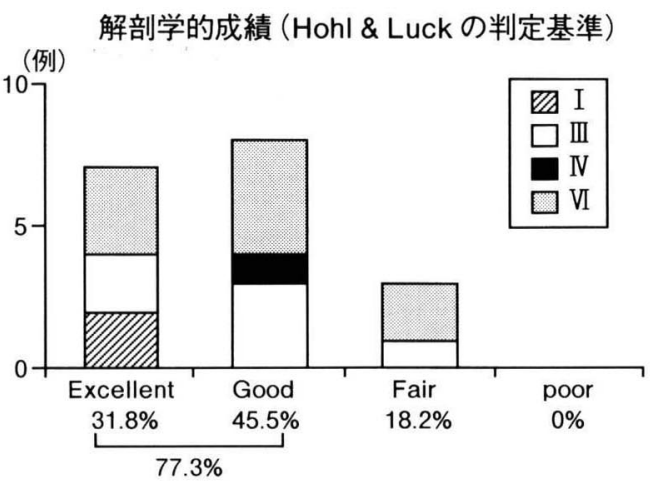

機能的成績 (Hohl \& Luck の判定基準)

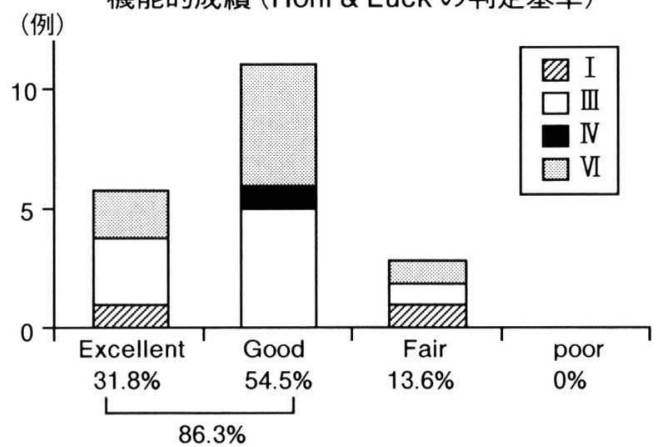

図-1 解剖学的成績は, Good 以上が $77.3 \%$ 機能的成績は, Good 以上が 86.3\%であった。
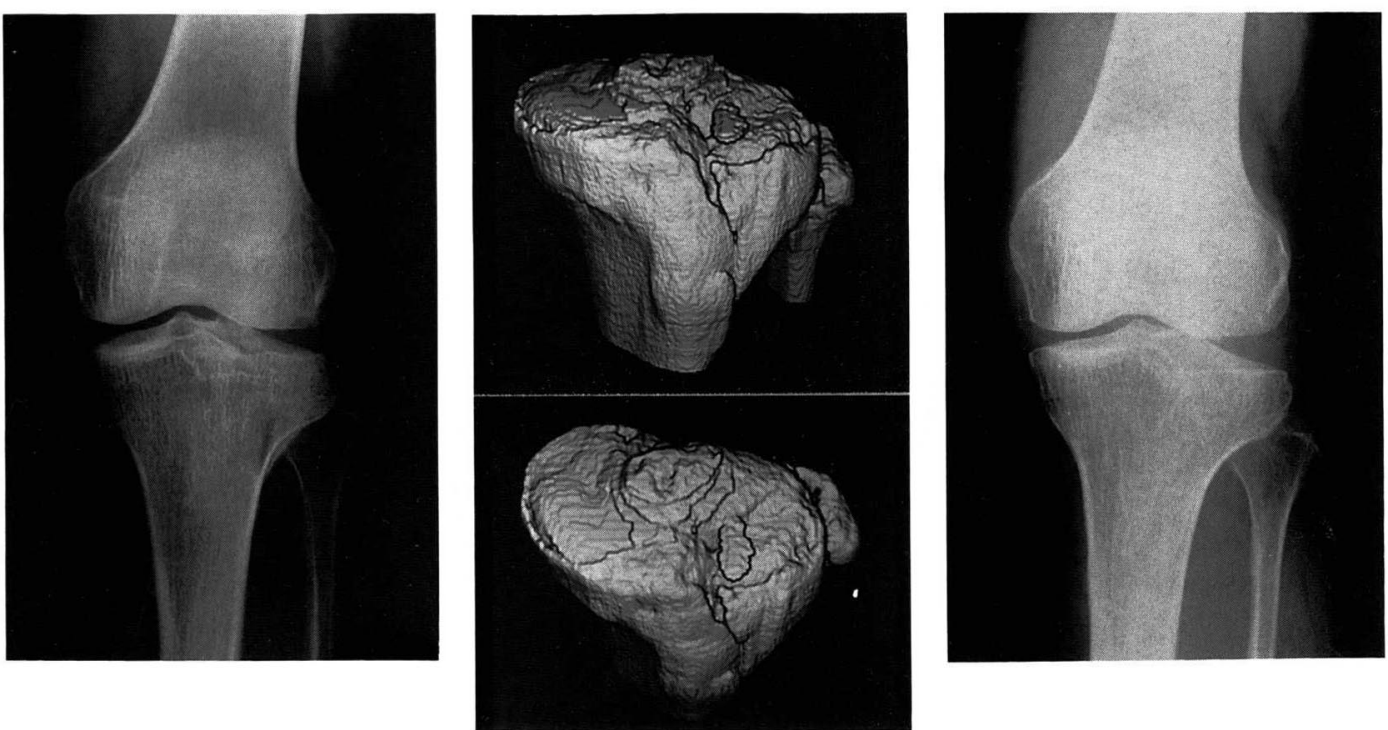

図-2 症例 1

受傷時 約 $3 \mathrm{~mm}$ の陥凹を認めたが (写真左, 中) 保存的治療中に陥凹の進行を認め, 受傷後 1 年 6 力月おいて約 $7 \mathrm{~mm}$ の陥凹となった (写真右). 
骨移植を行い，tibia bolt，plateにて強固な内固定を 行った。術後 3 日目からCPM にて可動域訓練を開始 し，12 週で全荷重歩行とした。術後 1 年での解剖学 的及び機能的評価は共に EXcellent であった（図一 3 ).

\section{考察}

脛骨プラトー骨折に対する治療目的は，関節面の正 確な整復と滕関節安定性の再建であり, 後の変形性膝 関節症への進展を予防することである。諸家の報 告 ${ }^{3) 4}$ によると， $5 \mathrm{~mm}$ 以下の陥凹は保存的に，10 $\mathrm{mm}$ 以上では観血的に治療が行われる例が多い，当 院においては， $5 \mathrm{~mm}$ 以上の陥凹，重篤な軟部組織
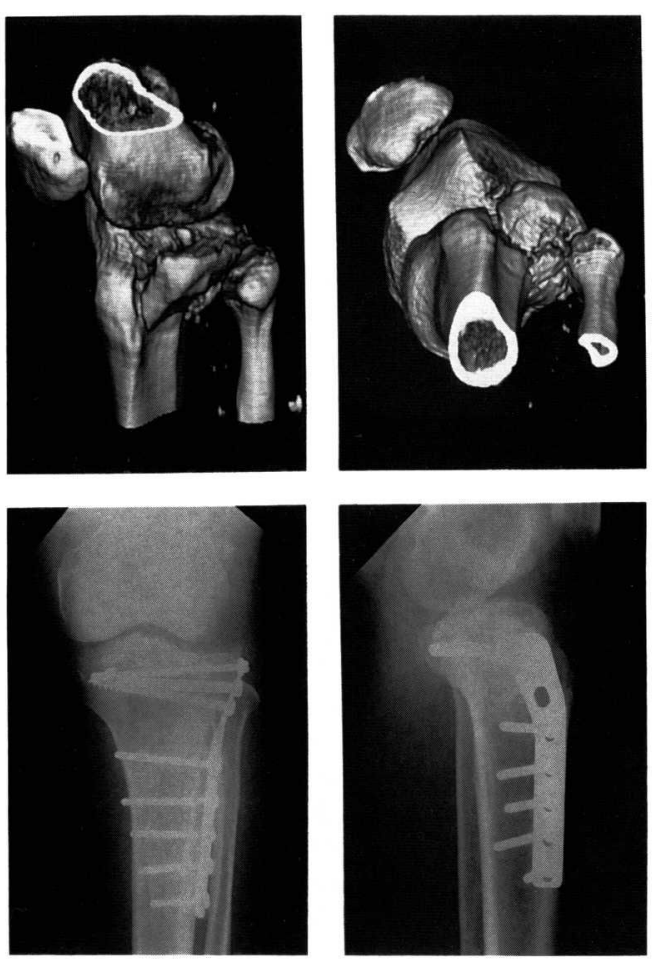

図 3 症例 2

術前 3 次元 CT (上段) にて約 $5 \mathrm{~mm}$ の陥凹を認め，骨移 植, プレート固定を行った (下段).
損傷，不安定型骨折について観血的治療を行ってきた 観血的治療例 20 例のうち術中所見にて骨欠損の大き い例, 海綿骨量の粗なもの 8 例に対して, 骨移植を行 い良好な結果を得たが，一方では術後に陥凹の進行し た例があった，術後レントゲンにて検討すると，プラ ト一部を矢状面にて前方部, 荷重部, 後方部に 3 分割 して考えた場合, 術前の陥凹部が荷重部から後方部に あるにも拘らず骨移植後の screw 刺入の位置がやや 前方寄りであったために固定性が低下したためと思わ れた。 又, 術中所見から骨移植不要と思われた症例で, 術後に陥凹を生じた例があり，その例でも陥凹がやや 荷重部寄りであった，奥村ら ${ }^{5)}$ の報告したように，前 方部の宿山例の予後は良好と思われるが，荷重部から 後方部寄りの骨折例では, 転位がわずかであ積極的に 骨移植を行うべきと思われた，術前の陥凹範囲の把握 は, 従来から単純 CT, 断層撮影で可能であるが, 今 回用いた 3 次元 CT にて, より立体的な把握が可能で あり, screw の刺入方向, 骨移植の重点筒所の決定に 有用之考えられる.

\section{ま と め}

1. 脛骨プラトー骨折 22 例について検討した.

2. 陥凹が荷重部から後方にある例では，転位がわ ずかでむ積極的に骨移植を行った方がよいと思われる.

3. 3 次元 $\mathrm{CT}$ による陥凹部の立体的把握が有用で あった。

\section{参 考 文 献}

1) Hohl M : Tibal condylar fracture. J Bone Joint surg 49- A : 1455-1467, 1967

2) Hohl M : Luck, J. V. : Fracture of the tibial condyle, a clinical and experimental study. J. Bone Joint surg 38-A : 1001-1005, 1956.

3）井上望, 須津富鵬 : 脛骨上端骨折, M. B. orthop. 37 : 43-53, 1991.

4）榊田喜三郎 他：脛骨近位部骨折の手術，臨整外 24 ： 1169-1177, 1989.

5）奥村 博 他：脛骨近位端骨折について, 整形外科 $20: 879-887,1969$. 